\title{
Use of Electronic Information Resources for Postgraduates Students of Gujarat University, Ahmedabad, Gujarat: A Survey
}

\section{Dr. Rajeshkumar M.Gamit}

\begin{abstract}
:
This research study aims to investigate the usage of electronic information resources by postgraduates' students of Gujarat University, Ahmedabad, Gujarat. Using the research is survey method approach, the simple random sampling was used to selected responded from among the postgraduate students from 200 to 500 all types of users that came to use the library within the study period. The research tool used for data collection was a questionnaire tagged "Usage of Electronic information resources". A total of 240 questionnaires were distributed of which 172 were duly filled giving a response rate of $71.66 \%$. The finding revealed that $89.54 \%$ of the respondents had use of electronic information resources; with $10.46 \%$ respondents are not use of electronic information resources. The main access points were home/hostels; only $19.76 \%$ of respondents had used the library to access electronic information resources and $80.24 \%$ of them were satisfied with the library electronic information resources. The major electronic information resources are used by postgraduate students were internet search engines, e-lecture notes and e-books and they use it for completing class assignments, to obtain course related materials. Training of postgraduate students in electronic information resources searching skill by the library; the provision of internet and networked computers in department and lecturers giving assignment that require use of electronic information resources would increase the use of electronic information resources among the postgraduate students.
\end{abstract}

Key Words: University Library, Electronic Information Resources, ICT, Postgraduate Students, Usage, Gujarat University.

\section{Introduction:}

Electronic information resources are today by far the most indispensable materials for acquiring knowledge and the best way to do this is through internet. There are many vendors 
who provide access to e- resources with attractive packages and over this access like Jstor, Taylor and Francis, Sage etc., then there are some who provide e-resources both for fees and for free like Google Scholar, Science Direct, Springer, Elsiver, MEDLINE, Thomson Reuters, Proquest, CAS, EBSCO, etc. databases are main electronic information resources in academic library user database services. Computer and communication are becoming the integral parts of the modern lives. The trends are changing due to the advancement of information and communication technology (ICT). Information and communication technology has changed the world and has become the important tool for retrieving information. Now days, library collections are not limited to print and non-printed document only but also included electronic information resources. The major development that is taking place in the Information and communication technology (ICT) today is widespread availability and use of various kind of electronic information resource which have been produced by applying modern information and communication technology. Information has become wider in present day research, covering non print materials. Library and information centers are required to support teaching, learning and research by incorporating electronic and digital information and professional's skills of all types of users.

Electronic Information Resources represent an in caressingly important component of the collection-building activities of libraries. "Electronic resources" refer to those materials that require computer access, whether through a personal computer, mainframe or handheld mobile device. They may either be accessed remotely via the Internet or locally. Some of the most frequently encountered types are: E-Journals, E-Books, E-database, E-thesis/ dissertation, Full-text databases, indexing and abstracting databases, Reference databasesBibliographies, Dictionaries, Directories, and Encyclopaedias' etc., Numeric and statistical databases- E-images, e-audio/visual resources. Electronic Sources are the clutch of technologies, which cover electronic information delivery includes CD-ROM, On-line database, Video text/teletext, DVD Rom databases, E-mail, Video Recording (Read-to-reel tape, Cartridges, Shorts, Cassettes and discs) motion pictures (loops, kinescope, stock, short, trailers, etc.) Microforms, Microfilms, Microfiches, Micro-opaque and aperture cards etc., Transparencies, locally loaded tapes, Internet, E-publishing, E-Journal, E-books, Radio, and Television etc.

Internet is network of networks, it provides seamless access to wide variety of information by not limited to a particular subject or language. In addition to traditional source teachers are forced to use electronic information resource, which is ranging from primary 
source for organizing their day to day teaching learning activities more creative. It is also necessary to create awareness among the academic community along with unfiltered information. Hence, we are motivated to conduct study on teachers approach to electronic information resources.

\section{Profile of Gujarat University, Ahmedabad:}

The Gujarat University was conceived in the nineteen twenties in the minds of publicspirited and learned men like Gandhiji, Sardar Patel, Acharya Anandshankar B., Dhruva, Dada Saheb Mavlanker, Kasturbhai Lalbhai and many others. However, the university could come into existence only after the achievement of independence. In 1949, the university was incorporated under the Gujarat University act of the state government 'as a teaching and affiliating university.' This was done as a measure of decentralisation and reorganization of university education in the then province of Bombay. Even then, the Gujarat University is the largest university in the state catering to the needs of higher education of more than two lakh students scattered over 235 colleges, 15 recognised institutions and 24 approved institutions. There are 34 post-graduate university departments and 221 P.G. Centers. Gujarat University has developed phenomenally in the last 68 years to be recognized as a premier University in the country today.

\section{Review of Literature:}

This research study regarding information is keys to the wellbeing of humanity and stand as the major determinant of decision making in electronic information resources. Okiki (2011) examined that information is the pivot on which the survival of any society rests. Nowadays, information could be accessed through a range of information and communication technology tools. Information and communication technology has transformed all human activities dependent on information, particularly in the area of poverty reduction, healthcare delivery and education. It has made a significant impact on teaching and learning in higher education and has improved the flow of information to academic communities. It has changed the philosophy of information from unitary to global access. The technological advancement has availed librarians the options of handling varied information sources conveniently and effortlessly.

Ellis and Oldman (2005) decide and justification that the use of electronic resources has availed researchers and students access to global information resources, particularly the Internet for their scholarly intercourse. Electronic scientific information resources have great 
significance in the advancement of teaching and learning. It has radically impacted the field of Library and Information Science to such an extent that access to information is now at fingertips. It has afforded users the opportunity of staying off- library and accessing eresources from diverse ends.

Sonkar et al. (2014) analysed listed the merits of electronic resources as follows: it can be access from any part of the globe without any geographical and time limitations, can be subscribed through consortia/ publisher, update, modification and alteration could easily be effected, availability in various files and formats immediately they are uploaded on the server saving time and money. It further posited that electronic resources can be searched, browsed, accessed, copied, downloaded fast and customized, Linking feature facilitates link within the documents as well as outside of the documents, many users can use electronic resources simultaneously, and it is possible to monitor the usage of electronic information resources to some extent.

Fidel et al. (1999) posited that "innumerable types of information, in a large variety of containers and in many different locations, are all available in one place. Electronic information resources have gained wide acceptability among university scholars due to its convenience, multi-access capability, unrestricted access to information, ability to browse the Web and timeliness. Thus, university libraries in their quest to fulfil their role as information reservoir in support of teaching, learning and research are increasingly acquiring”.

Electronic Information Resources for optimum use of their librarian, faculty, postgraduate students and other members of the academic libraries now have access to diversified formats of information such as print and non-print, leading to a greater need for research assistance from librarians to achieve improved access facilities for information retrieval, and study regarding prefer at any point of view in any time, access to a vast array of information from where selection could be made. The academic library services of information specialists are needed for users of library to make optimum use of available electronic information resources and to locate needed information. Bhatt (2012) states that the online resources and databases are also a scholarly source where the information is stored updated and latest so law faculty members prefers to access online information. Talati and Bhatt (2016) The first possible applications of mobile technology for libraries were the mobile OPACs and mobile collections and mobile library instruction, as well as databases

\section{Statement of the research problem:}


This study main mission of academic libraries is to postgraduate students supporting learning and research activities; simulate creativity and intellectual development and acquisition of knowledge. Gujarat university library in living up to this expectation has devoted a substantial part of its financial condition of budget to libraries. The library has been collection of all types of electronic information resources such as CD-ROM databases, ebooks, e-journals, online database and online public access catalogues (OPAC). It is against this background that the study topic "Use of Electronic Information Resources for Postgraduates Students of Gujarat University, Ahmedabad, Gujarat”.

\section{Objectives of the Study:}

The following are the objectives guiding the study:

- To assess the level of computer proficiency of Postgraduate Students in Gujarat University.

- To ascertain postgraduate students level of use of electronic information resources.

- To find out the purpose of use of electronic information resources.

- To find out of the location of postgraduate students access to electronic information resources.

- To determine postgraduate students constraints in accessing and using electronic information resources.

\section{Methodology:}

The research is survey method was adopted for the study. The postgraduate students from 180 level and above of Gujarat University, Ahmedabad, Gujarat that used the library within the study period constituted the information literacy for the study. The simple random sampling was adopted selecting the postgraduate students as they come to make use of the "Gujarat University Library". The research tools used was questionnaire tagged "Use of Electronic Information Resources". The questionnaire was administered on 180 postgraduate students as they visited the library and the completed questionnaire was collected back from them before they leave the library. The number of questionnaire returned that were duly filled by the postgraduate students was 168 giving the overall response rate 93\%. The data generated was analyzed using frequency counts and simple percentages. 


\section{Result Discussion and Findings:}

Data Analysis Showing review framework on e-resources

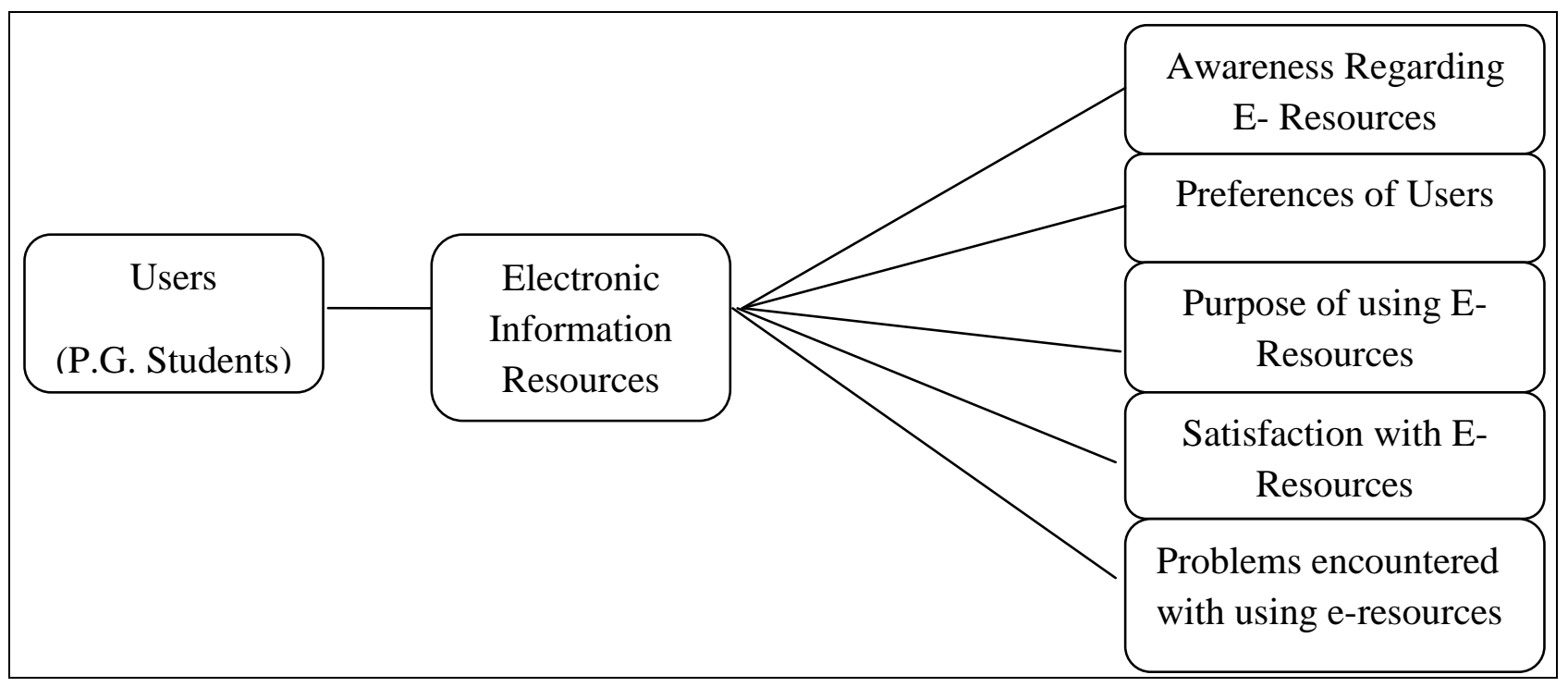

\section{Demographic of the Respondents:}

Table No. 1 Department Wise Students

\begin{tabular}{|l|c|c|}
\hline Departments & No. Respondents & Percentage \\
\hline School of Science & 58 & $33.71 \%$ \\
\hline School of Social Science & 40 & $23.25 \%$ \\
\hline School of B. K. Management & 38 & $22.10 \%$ \\
\hline School of Languages & 36 & $20.94 \%$ \\
\hline \multicolumn{1}{r|}{ Total } & $\mathbf{1 7 2}$ & $\mathbf{1 0 0 . 0 0 \%}$ \\
\hline
\end{tabular}

The table No. 1 shows that 168 (100\%) respondents are four department of Gujarat University in Ahmedabad, Gujarat are School of Science 58 (33.72\%), School of Social Science 40 (23.25\%), School of B. K. Management 38 (22. 10\%), and School of Languages $32(20.94 \%)$ 
Table No. 2 Gender wise Used in Electronic Resources of P. G. Students

\begin{tabular}{|l|c|c|}
\hline Gender & No. Respondents & Percentage \\
\hline Male & 102 & $59.30 \%$ \\
\hline Female & 70 & $40.69 \%$ \\
\hline & $\mathbf{1 7 2}$ & $\mathbf{1 0 0 . 0 0 \%}$ \\
\hline
\end{tabular}

The table no. 2 shows the gender wise used in electronic resources of P.G. Students in four department of Gujarat University in Ahmedabad, Gujarat. Out of 102 (59.30\%) P.G. Students are Male and 70 (40.69\%) P.G. Students female.

Table No. 3 Age Group of P.G. Students

\begin{tabular}{|c|c|c|c|c|c|c|}
\hline $\begin{array}{c}\text { Age } \\
\text { Group } \\
\text { of P. G. } \\
\text { Students }\end{array}$ & $\begin{array}{c}\text { School } \\
\text { of } \\
\text { Science }\end{array}$ & $\begin{array}{c}\text { School of } \\
\text { Social } \\
\text { Science }\end{array}$ & $\begin{array}{c}\text { B.K School } \\
\text { of } \\
\text { Management }\end{array}$ & $\begin{array}{c}\text { School of } \\
\text { Languages }\end{array}$ & $\begin{array}{c}\text { Total No. } \\
\text { of } \\
\text { Students }\end{array}$ & $\begin{array}{l}\text { Percentage } \\
(\%)\end{array}$ \\
\hline $\begin{array}{c}\text { Below } \\
21\end{array}$ & 13 & 15 & 12 & 16 & 56 & $32.55 \%$ \\
\hline $22-26$ & 10 & 15 & 8 & 10 & 43 & $25.00 \%$ \\
\hline $27-31$ & 9 & 7 & 6 & 7 & 29 & $16.86 \%$ \\
\hline $31-35$ & 8 & 6 & 2 & 3 & 19 & $11.05 \%$ \\
\hline $36-40$ & 4 & 3 & 3 & 4 & 14 & $8.14 \%$ \\
\hline above 41 & 2 & 1 & 4 & 4 & 11 & $6.40 \%$ \\
\hline Total & $\mathbf{4 6}$ & $\mathbf{4 7}$ & $\mathbf{3 5}$ & $\mathbf{4 4}$ & $\mathbf{1 7 2}$ & $\mathbf{1 0 0 . 0 0 \%}$ \\
\hline
\end{tabular}

The table No. 3 indicates the Age-group of P.G. Students in four department of Gujarat University in Ahmedabad, Gujarat. Out of 56 (32.55\%) P.G. Students are age group below 21 years. 43 (25.00\%) P.G. Students age group of 22-26 year. 29 (16.86\%) P.G. Students age group of 27-31 year. 19 (11.05\%) P.G. Students age group of 31-35 year. 14 (8.14\%) P.G. Students age group 36-40 year and 11 (6.40\%) P.G. Students are age group of above 41 years.

Table No. 4 Computer Proficiency Skill of P.G. Students

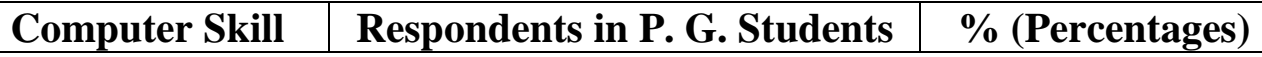




\begin{tabular}{|l|c|c|}
\hline Excellent & 29 & $16.86 \%$ \\
\hline Very Good & 50 & $29.07 \%$ \\
\hline Good & 62 & $36.05 \%$ \\
\hline Average & 18 & $10.46 \%$ \\
\hline Poor & 8 & $4.65 \%$ \\
\hline No. Response & 5 & $2.91 \%$ \\
\hline \multicolumn{1}{r|}{ Total } & $\mathbf{1 7 2}$ & $\mathbf{1 0 0 . 0 0 \%}$ \\
\hline
\end{tabular}

The P.G. Students should have the skills to use of computer and self-rating of computer proficiency by the responded in table no 4 shows that $62(36.05 \%)$ of respondents perceived themselves to be good in the use of computer, 50 (29.07\%) of the respondents felt that they have a very good skill in computer while only, 29 (16.86\%) rated themselves excellent in their computer skill, $18(10.46 \%)$ rated themselves as average while an insignificant proportion of $8(4.65 \%)$ of the respondents computer skill themselves poor in use of computer. If we pool together the respondents that indicated Good, Very Good and Excellent computer skill use of computer in P. G. Students

Table No. 5 Use of Electronic Information Resources in P. G. Students

\begin{tabular}{|c|c|c|}
\hline Use of EIR & $\begin{array}{c}\text { Respondents in P. G. } \\
\text { Students }\end{array}$ & Percentage \\
\hline Yes & 154 & $89.54 \%$ \\
\hline No & 18 & $10.46 \%$ \\
\hline Total & $\mathbf{1 7 2}$ & $\mathbf{1 0 0 . 0 0 \%}$ \\
\hline
\end{tabular}

Table No. 5 shoes that majority of the respondents 154 (89.54\%) indicated the use while only a few of them $18(10.46 \%)$ do not use electronic resources.

Table No. 6 Access Point of Electronic Information Resources in P. G. Students

\begin{tabular}{|c|c|c|}
\hline Access Points & $\begin{array}{c}\text { Respondents in P. G. } \\
\text { Students }\end{array}$ & Percentage \\
\hline Home and Hostels & 34 & $19.76 \%$ \\
\hline University Library & 138 & $80.24 \%$ \\
\hline Total & $\mathbf{1 6 8}$ & $\mathbf{1 0 0 . 0 0 \%}$ \\
\hline
\end{tabular}

Table no. 6 show the main access points were home/hostels; only 34(19.76\%) of respondents had used the library to access electronic information resources and 138 (80.24\%) of them were satisfied with the library electronic information resources.

Table No. 7 Frequency of Use of Electronic Information Resources 


\begin{tabular}{|c|c|c|}
\hline Frequency & $\begin{array}{c}\text { Respondents in P.G. } \\
\text { Students }\end{array}$ & Percentage $(\%)$ \\
\hline Daily & 32 & $18.60 \%$ \\
\hline Once in two days & 20 & $11.62 \%$ \\
\hline Once in week & 38 & $22.10 \%$ \\
\hline Once in Fortnightly & 16 & $9.30 \%$ \\
\hline Once in Month & 12 & $6.98 \%$ \\
\hline Occasionally & 54 & $31.40 \%$ \\
\hline Total & 172 & $100.00 \%$ \\
\hline
\end{tabular}

Table No. 7 indicates the respondents that used electronic resources occasionally were in the majority 54 (31.40\%), 38 respondents $(22.10 \%)$ used electronic information resources one in a week, $32(18.60 \%)$ respondents using it daily. 20 (11.62\%) respondents are used electronic information resources once in two days, $16(9.30 \%)$ respondents once in fortnightly and $12(6.98 \%)$ respondents are used in once month.

Table No. 8 Types of Electronic Information Resources used

\begin{tabular}{|l|c|c|}
\hline EIR Types & $\begin{array}{c}\text { Respondents in P.G. } \\
\text { Students }\end{array}$ & Percentages (\%) \\
\hline Internet Searching Engines as Google & 41 & $23.84 \%$ \\
\hline E-Books & 29 & $16.86 \%$ \\
\hline E-journals & 21 & $12.20 \%$ \\
\hline E- databases & 22 & $12.80 \%$ \\
\hline E-Theses and Dissertations & 11 & $6.40 \%$ \\
\hline E-Lecture Notes & 28 & $16.28 \%$ \\
\hline E-Newspapers & 14 & $8.14 \%$ \\
\hline E- Conference Proceedings Tral & $\mathbf{1 7 2}$ & $3.48 \%$ \\
\hline \multicolumn{2}{r}{ Total } & $\mathbf{1 0 0 . 0 0 \%}$ \\
\hline
\end{tabular}

Table no. 8 show the indicate that $41(23.84 \%)$ students used internet search engines as Google, 29 (16.86\%) students are use of e-books, followed by e-lecture notes 28 (16.28\%) and $22(12.80 \%)$ students are use of e-database. The electronic information resources least utilized were e-conference proceeding $6(3.48 \%)$.

Table No. 9 Purpose of Use of Electronic Information Resources

\begin{tabular}{|l|c|c|}
\hline \multicolumn{1}{|c|}{ Purpose } & $\begin{array}{c}\text { Respondents } \\
\text { in P.G. } \\
\text { Students }\end{array}$ & $\begin{array}{c}\text { Percentages } \\
\text { (\%) }\end{array}$ \\
\hline Class Assignment & 42 & $24.42 \%$ \\
\hline Research purpose & 28 & $16.28 \%$ \\
\hline Study materials & 22 & $12.80 \%$ \\
\hline Recommended by Lecturers & 25 & $14.52 \%$ \\
\hline
\end{tabular}




\begin{tabular}{|c|c|c|}
\hline Seminar, Oral and Class presentation & 18 & $10.46 \%$ \\
\hline Update knowledge & 15 & $8.72 \%$ \\
\hline Entertainment & 12 & $6.98 \%$ \\
\hline Leisure & 10 & $5.82 \%$ \\
\hline Total & 172 & $100.00 \%$ \\
\hline
\end{tabular}

Table no. 9 response to the question on purpose of use of e-resources, the highest number of respondents $42(24.42 \%)$ were using electronic information resources to complete class assignments, $28(16.28 \%)$ student are using research purpose, followed by $22(12.80 \%)$ that were using it to obtain course related information and study materials. $25(14.52 \%)$ respondents to recommended by lecturers, $18(10.46 \%)$ students are attendant seminar, oral and class presentation, $15(8.72 \%)$ students update knowledge. Those using electronic information resources for entertainment $12(6.98 \%)$ and leisure $10(5.82 \%)$ were the least.

Table No. 10 Quality of Electronic Information Resources

\begin{tabular}{|c|c|c|}
\hline Quality & Respondents & Percentage (\%) \\
\hline Excellent & 32 & $18.60 \%$ \\
\hline Very Good & 52 & $30.24 \%$ \\
\hline Good & 42 & $24.42 \%$ \\
\hline Average & 30 & $17.44 \%$ \\
\hline Poor & 16 & $9.30 \%$ \\
\hline Total & 172 & $100 \%$ \\
\hline
\end{tabular}

Table no. 10 indicates that majority of the respondents 52 (30.24\%) rated Gujarat University Library e-resources as Very Good, while about 42 (24.42\%) respondents are indicated Good. $32(18.60 \%)$ respondents that rated the electronic information resources as Excellent, $30(17.44 \%)$ respondents are Average and $16(9.30 \%)$ respondents are rated the electronic information resources as Poor.

\section{Table No. 11 Devices Used by P. G. Students to Access} Electronic Information Resources

\begin{tabular}{|l|c|c|}
\hline Devices & Respondents & Percentage (\%) \\
\hline Desktop & 35 & $20.35 \%$ \\
\hline Laptop & 49 & $28.48 \%$ \\
\hline Mobile Phones & 64 & $37.21 \%$ \\
\hline I Pad & 24 & $13.96 \%$ \\
\hline \multicolumn{1}{|c|}{ Total } & $\mathbf{1 7 2}$ & $\mathbf{1 0 0 \%}$ \\
\hline
\end{tabular}

Table No. 11 shows that majority of the respondents used their out of 64 (37.21\%) Mobile Phones to access electronic information resources, 49 (28.48\%) respondents are that used 
Laptop. Followed by 35 (20.35\%) that used desktop computers while 24 (13.96\%) respondents used I-Pad.

Table No. 12 Formal Training on Electronic Information Resources accessing and usage by P. G. Students

\begin{tabular}{|c|c|c|}
\hline Frequency & Respondents & Percentage (\%) \\
\hline Yes & 118 & $68.60 \%$ \\
\hline No & 54 & $31.40 \%$ \\
\hline Total & 168 & $100.00 \%$ \\
\hline
\end{tabular}

Table no. 12 indicates that $118(68.60 \%)$ respondents had formal training on how to use electronic resources as against $54(31.40 \%)$ respondents that did not receive formal training.

Table No. 13 Need for Training on Electronic Information Resources Usage by P. G. Students

\begin{tabular}{|c|c|c|}
\hline Frequency & Respondents & Percentage $(\%)$ \\
\hline Yes & 145 & $84.30 \%$ \\
\hline $\mathrm{No}$ & 27 & $15.70 \%$ \\
\hline Total & 172 & $100.00 \%$ \\
\hline
\end{tabular}

Table no. 13 shows that need for training on how to maximise the use of e-resources was indicated by majority of the respondents 145 (84.30\%) and while a few of them $27(15.70 \%)$ respondents did not want to be trained in accessing electronic information resources.

Table No. 14 Obstruction to access and use of Electronic Information Resources

\begin{tabular}{|l|c|c|}
\hline Obstruction & Respondents & Percentage (\%) \\
\hline Limited Access to Internet & 24 & $13.94 \%$ \\
\hline Time consuming and Waste a lot of time & 17 & $9.88 \%$ \\
\hline Slow Internet Speed & 25 & $14.54 \%$ \\
\hline Insufficient skill to retrieve needed information & 30 & $17.45 \%$ \\
\hline The use of e-resources distracts one from doing other works & 14 & $8.14 \%$ \\
\hline High costs of accessing electronic resources & 11 & $6.40 \%$ \\
\hline Lack of time & 27 & $15.70 \%$ \\
\hline The library staff are not cooperative to facilitate easy use & 8 & $4.65 \%$ \\
\hline Some full texts require subscription or payment & 16 & $9.30 \%$ \\
\hline & $\mathbf{1 7 2}$ & $\mathbf{1 0 0 . 0 0 \%}$ \\
\hline
\end{tabular}

Table no. 14 respondents ware requested to indicate the obstruction faced in the use of electronic information resources. The most common obstruction students was insufficient skill to retrieved needed information cited by 30 (17.45\%) of respondents. Next respondents were lack of time to access electronic information resources 27 (15.70\%). The other 
obstruction mentioned by 25 (14.54\%) of respondents were slow internet speed, 24 (13.94\%) respondents are limited access to internet. 17 (9.88\%) respondents are time consuming and waste a lot of time, $16(9.30 \%)$ respondents are some full texts require subscription or payment, $11(6.40 \%)$ respondents are high costs of accessing electronic resources and $8(4.65 \%)$ library staff are not cooperative to facilitate easy use of respondents.

\section{Conclusions, Findings and Recommendations:}

There should be more user using awareness of electronic information resources by the university and the library in particular to market the different types of e-resources are available in the university library. The library should put in place strategies that will promote and monitor on a regular basis the use of electronic information resources by postgraduates' student's members of the university community. Finding and recommendation of further research study are following:

- This research study found that the usage of electronic information resources is widespread among the Post Graduates students.

- However, only about half of the students are frequent users and the postgraduates' students used mainly their laptops and desktops to access electronic resources mainly from home and hostels. While only a few of them had used the library to gain access.

- The postgraduate's students used electronic information resources for completing their class assignments to get course related materials and to update knowledge.

- Lack of skills, difficulty in findings relevant information,

- Lack of time and frequent power outage were the major factors militating against effective use of electronic information resources.

- The university and the library should make effort to organise more in depth training for effective use of electronic information resources by the postgraduate students.

- Through electronic information resources about the presently included in the use of library which is a compulsory course for all postgraduate students, however the teaching needs to be made more practical. 
- The course should not only focus on how postgraduate students should locate electronic information resources, but should also include how they can use electronic information resources to attain their academic goals.

The university should install networked computers in sufficient numbers in departments and faculties so that postgraduates' students could also use these avenues to access electronic information resources. It will also make it possible for the professor, associate professor and assistant professors to be involved in the impartation of skills for accessing electronic information resources on the postgraduates' students.

\section{References:}

1. Adeniran, P. (2013) Usage of electronic resources by undergraduates at the Redeemers University, Nageria, International Journals of Library and Information Science Vol. 5 (10) pp. 319-321.

2. Bhatt A. A. (2014), Information needs, perceptions and quests of law faculty in the digital era. The Electronic Library, 32(5), 659-669. http://doi.org/10.1108/EL-112012-0152

3. Dhanavandan, S. And Tamizhchelvan, M. (2012) “An Evolution of E-Resources in academic libraries in Tamil Nadu" Journals of Emerging Trends in Computing and Information Science, Vol. 3, No. 3, Pp. 421-426.

4. Ellis, D. and Oldman, H (2005) the English literature researcher in the age of Internet, Journal of Information Science Vol. 31, No. 1.

5. Fidel, R. D., Dougleass, R. K., Holder, M. H., Hokins, J. K., Kushner, C. S., Miyagishimma, B. K. And Toney, C. D. (1999). A visit to the information mall: web searching behaviour of high school students. Journal of the American Society for Information Science, 50 (1), pp.24-37.

6. Hadagali, G.S. and Nelogal, S. B. (2010) "Use of Electronic Resources by PostGraduate Students in Different Universities of Kanrataka State", International Journals of Information Dissemination and Technology, Vol. 2, Issue, 3, pp. 189-195.

7. Okiki, O.C. and Asiru, S. M. (2011) Use of Electronic Information Sources by Postgraduate Students in Nigeria: Influencing Factors. Library and Philosophy and Practice (e-Journals). 
8. Sonkar, S. K. (2014) Use of Electronic Resources by Post Graduate Students and Research Scholar of the Banaras Hindu University: A Study, Journal of Information Management 1-2, pp. 87-97.

9. Talati, Yatin \& Bhatt, Atul (2016). WEBBASED LIBRARY RESOURCES AND SERVICES: A RELATIVE STUDY OF IITS AND NITS, Voice of Research, 5(3), 17-19.

10. Taviyad, R. H. (2015) Use of E-Resources in Medical College Libraries: A Study Based on Gujarat State, IJAPRR, International Peer Reviewed Refereed Journal, Vol. II, Issue, X, pp. 05-10.

Webliography:

- http://WWW.jstor.org. (JSTOR)

- http://www.scholar.google.co.in (Google Scholar)

- http:// www.sciencedirect.com (Science Direct)

- http://www.inflibnet.ac.i (INFLIBNET)

- http://www.delnet.nic.in (DELNET)

- http://www.academicjournals.org/IJLIS

- $\quad$ www.gujaratuniversity.org.in

\section{Dr. Rajeshkumar M.Gamit}

Assistant Professor

Department of Library and Information Science

Gujarat University, Ahmedabad-380009

Email: rajeshkumargamit@gmail.com 